\title{
Seasonal Growth and Reproduction of the Black goby, Gobius niger (Osteichthyes: Perciformes: Gobiidae) in the southeastern Black Sea Region of Turkey
}

\author{
Sabri BILGIN* Hatice ONAY \\ ${ }^{1}$ University of Sinop, Fisheries Faculty, Department of Fisheries, Sinop, Turkey. \\ ${ }^{2}$ Recep Tayip Erdoğan University Faculty of Fisheries and Aquaculture, TR53000, Rize, Turkey.
}

How to cite: Bilgin, S. \& Onay, H. (2020). Seasonal Growth and Reproduction of the Black goby, Gobius niger (Osteichthyes: Perciformes: Gobiidae) in the southeastern Black Sea Region of Turkey. J. Anatolian Env. and Anim. Sciences, 5(4), 466-474.

Atıf yapmak için: Bilgin, S. \& Onay, H. (2020). Türkiye'nin Güneydoğu Karadeniz Kıyılarında Kömürcü Baya Balığının, Gobius niger (Osteichthyes: Perciformes: Gobiidae), Mevsimsel Büyümesi ve Üremesi. Anadolu Çev. ve Hay. Dergisi, 5(4), 466-474.

*Corresponding author's: Sabri BİLGIN

University of Sinop, Fisheries Faculty, Department of Fisheries, Sinop, Turkey. 凶: sbrbilgin@hotmail.com

Telephone : +90(368) $2876254 / 3391$ Fax : $+90(368) 2876269$

\begin{abstract}
Seasonal growth pattern and reproductive biology of the black goby, Gobius niger ( $\mathrm{n}=$ 568; 2.1-14.6 cm TL), were monthly studied in southern Black Sea between December 2012 and November 2013. The seasonal von Bertalanffy growth parameters, computed from ELEFAN, were estimated as $L_{\infty}=11.9 \mathrm{~cm} T L, K=0.701 \mathrm{year}^{-1}, C=0.633$, and $W P=0.492$ for the Hoenig seasonal model and as $L_{\infty}=12.1 \mathrm{~cm} T L, K=0.680$ year $^{-1}$ for non-seasonal von Bertalanffy model. The size at sexual maturity $\left(L_{m}\right)$ was estimated as $8.9 \mathrm{~cm} T L$. The Gonadosomatic index (GSI) ranged between 0.60 in December and 8.57 in April 2013 (mean 3.82 \pm 0.82 ) for females and 0.61 in October 2013 and 2.90 in May 2013 (mean 1.70 \pm .26) for males. The seasonal growth was pronounced probably due to reproduction activity which extended investment of energy in reproduction causing slower growth. The GSI development was related to photoperiod and the monthly variations of GSI values indicating that the intensive spawning occurred between April 2013 and August 2013. During spawning time, the mean GSI value of females $(6.04 \pm 1.18)$ was 2.9 times higher than the mean GSI values of males $(2.08 \pm 0.42)(P<0.05)$. The results of this study were offered as biological input parameters regarded as a reference for the conservation and management of the Black Sea stocks of the black goby.
\end{abstract}

\section{Türkiye'nin Güneydoğu Karadeniz Kıyılarında Kömürcü Baya Balığının, Gobius niger (Osteichthyes: Perciformes: Gobiidae), Mevsimsel Büyümesi ve Üremesi}

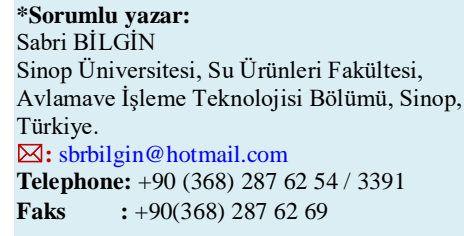

\begin{abstract}
Öz: Güneydoğu Karadeniz kıyılarında kömürcü kaya balığının, Gobius niger (n= 568; 2,1-14,6 cm TB), üremesi ve mevsimsel büyümesi Aralık 2012 ve Kasım 2013 arasında aylık olarak çalıșılmıștır. ELEFAN'a göre hesaplanan mevsimsel von Bertalanffy büyüme denklemi parametreleri; Hoenig mevsimsel modele göre $L_{\infty} 11,9 \mathrm{~cm} T B ; K=0,701 \mathrm{yll}^{-1} ; C=0,633$ ve $W P=$ 0,492 olarak, mevsimsel olmayan von Bertalanffy büyüme modeline göre ise $L_{\infty}=12,1 \mathrm{~cm} T B$, $K=0,680 \mathrm{yll}^{-1}$ şeklinde hesaplanmıștır. Cinsi olgunluk boyu $\left(L_{m}\right) 8,9 \mathrm{~cm} T B$ olarak hesaplanmıștır. Gonadosomatik indeks (GSI) değeri dişiler için 0,60 (Aralık 2012) ile 8,57 (Nisan 2013) arasında (ortalama 3,82 $\pm 0,82$ ), erkekler için ise 0.61 (Ekim 2013) ve 2.90 (Mayıs 2013) arasında (ortalama $1,70 \pm 0,26)$ değişmiştir. Mevsimsel büyüme, muhtemelen daha yavaş büyümeye neden olan üreme faaliyeti nedeniyle belirgindi. Aylı GSI gelișimi, fotoperiyod ile ilișkili olup yumurtlamanın Nisan 2013 ve Ağustos 2013 arasında gerçekleştiğini göstermiştir. Üreme süresince, dişiler için hesaplanan ortalama GSI değerinin $(6,04 \pm 1,18)$, erkelerin ortalama GSI değerinden $(2,08 \pm 0,42)$ yaklaşı 2,9 kat daha büyük olduğu hesaplanmıştır $(P<0,05)$. Bu çalışmanın sonuçları, kaya balığının Karadeniz'deki stoklarının korunması ve yönetimi için biyolojik girdi parametreleri olarak sunulmuştur.
\end{abstract}

Anahtar kelimeler: ELEFAN, fotoperiyod, mevsimsel büyüme, üreme. 


\section{INTRODUCTION}

Black goby, Gobius niger Linnaeus, 1758, is widely distributed from Norway to the Canary Islands and Mauritania, all coasts of the Mediterranean Sea and the Black Sea (Bouchereau \& Guelorget, 1998; Froese \& Pauly, 2019; Kara \& Quignard, 2019). The black goby is a large species growing to over $15 \mathrm{~cm}$ and it quite enjoys harbours and brackish waters, where it is at home in estuaries, coastal lagoons and sea lochs (Kara \& Quignard, 2019). It is very territorial in nature and is locally common on all sandy sea beds, preferring the shelter of nearby reefs and seagrass meadows (Wood, 2015; Kara \& Quignard, 2019) and lives in coastal marine waters up to $80 \mathrm{~m}$ in depth, but most often between the surface and $30 \mathrm{~m}$ (Kara \& Quignard, 2019). Sexually mature at one or two years of age, the territorial males and juveniles are jet black and have a life span of five years (Silva \& Gordo, 1997; Bouchereau \& Guelorget, 1998; Kara \& Quignard, 2019).

References used for the black goby comprising distribution and habitat selection, feeding ecology and behavior, genetic, environmental effects and pollution, growth and reproduction biology were cited in the introduction section by the Filiz \& Toğulga (2009) and also listed in the Froese \& Pauly (2019). Moreover, nomenclature, description, distribution, ecology (e.g. habitat, migration, lifespan and growth, feeding and feeding behavior), reproduction and reproductive behavior (sexuality, maturity and spawning behavior) and pollution of the black goby have been globally reviewed by Kara \& Quignard, (2019). In the European coasts (e.g. Norway, Netherlands, Portugal, France, Italy), reproduction biology, age and growth of the black goby were reported by different authors (Vaas et al., 1975; Fabi \& Giannetti, 1983; Nash, 1984; Arruda et al., 1993; Joyeux et al., 1991; Silva \& Gordo, 1997; Bouchereau \& Guelorget, 1998; Immler et al., 2004). Reproductive biology of the black goby in the Mediterranean, Gulf of Gabès, Tunisia was also studied by Hajji et al. (2013). Moreover, studies on the black goby in the coast of Turkey were carried out on their age, growth and reproduction biology in the Bay of Izmir, Aegean Sea (Özaydın et al., 2007; Kınacıgil et al., 2008; Filiz \& Toğulga, 2009) and in the Sea of Marmara (Kırdar \& İşmen, 2018). Feeding ecology of the black goby in the Aegean Sea was also studied by Filiz \& Toğulga (2009).

Although the growth and reproductive biology of the black goby has been reported in detail in other geographical regions, surprisingly there is no published study about the biology for this species commonly found in the Black Sea. Since it has no commercial value in the Black Sea, probably, fisheries biologists did not give enough attention of its biology. In recent years, the black goby has been rarely sold at fishing stalls in the Black Sea regions (e.g. Sinop) and it has rarely been bought and consumed by people (personal observations). However, this species has important ecologic values and it has an important role in the food chain (Filiz \& Toğulga, 2009; Kara \& Quignard, 2019). Namely, in the Venetian lagoon, the diet of the black goby is related to its habitat rich in seed plants and algae (Franco et al., 2006). The preferred preys are primarily crustaceans and secondarily mollusks, polychaete annelids, etc. Large individuals also consume small fish such as pupfishes, silversides, gobies (Casabianca \& Kiener, 1969) in the Corsican lagoons of Diana and Urbino. The black goby individuals feed on mainly Mollusca, Crustacea, Polychaeta, Foreminifera and Teleostei in the Gulf of Izmir, Aegean Sea (Filiz \& Toğulga, 2009). Moreover, it is used as a bioindicator of pollution (Maradonna \& Carnevali, 2007; Barucca et al., 2006). Therefore, the black goby is in the food chain of commercial fish with high economic value such as turbot, consumed by humans (personal observations). These increase the ecological value of the black goby.

This paper provides the first information on the black goby specifically on its seasonal growth and reproduction and also to assess the differences in these parameters in other studies.

\section{MATERIAL AND METHOD}

Study area and sampling: Samples were monthly collected using an experimental purposes beam trawl with $15 \mathrm{~mm}$ cod-end stretched mesh size up to $30 \mathrm{~m}$ water depths from December 2012 to November 2013 on the Rize province coasts of the southeastern Black Sea, Turkey (Figure 1). All samples were taken from the same locality during daylight. Although beam trawl fishery is banned in the Rize province coasts of the southeastern Black Sea during the year, sampling surveys were conducted with a special permit from the General Directorate of Fisheries and Aquaculture, the Ministry of Agriculture and Forestry of Turkey. The total length (TL) was measured after blot drying with a piece of clean towel. All specimens were measured to the nearest $1 \mathrm{~mm}$, total wet weight $(W)$ and gonad weight $\left(W_{g}\right)$ were also recorded to the nearest $0.1 \mathrm{~g}$. The sex determination was conducted by macroscopic and/or microscopic examination of the gonads.

Day length (hour) data reported by Bilgin et al. (2009a) and annual sea surface temperature (SST, ${ }^{\circ} \mathrm{C}$ ) data reported by Çakıroğlu et al. (2017), provided from Meteorological Data Information System (https://mevbis.mgm.gov.tr/mevbis), were used to determine the effect of day length and temperature on reproduction.

Growth estimation: Growth in length has been described using the von Bertalanffy (1938) growth equation, based on either observed or back calculated length at ages. The length frequency distribution analysis (LFDA) PC based 
computer package (version 5.0) includes methods for estimating the parameters of both non seasonal and Hoenig seasonal versions of the von Bertalanffy growth curve for estimating growth parameters from fish LFDs (Kirkwood et al., 2003).

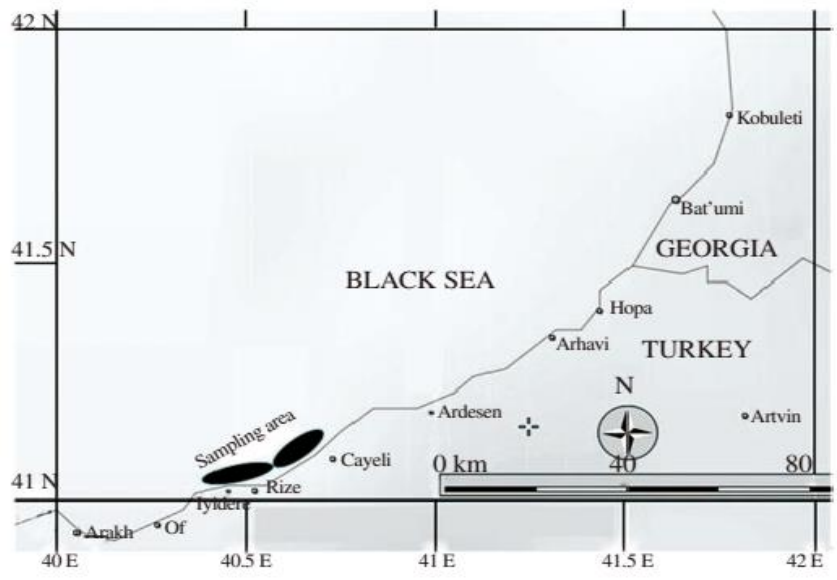

Figure 1. Beam trawl fishing operations sampling area around the Rize province in the Southeastern Black Sea, Turkey.

The classic parameterization of the standard or three parameters von Bertalanffy growth function (3P VBGF) was proposed by Beverton \& Holt (1957) and is:

$$
L_{t}=L_{\infty}\left(1-e^{-k\left(t-t_{0}\right)}\right) \text {. }
$$

Seasonal growth or five parameters von Bertalanffy growth function (5P VBGF) was described using the Somers's (1988) version of the VBG equation:

$$
\left.L_{t}=L_{\infty}\left[1-e^{\left[-K\left(t-t_{o}\right)-\left(C \frac{K}{2 \pi}\right) \sin 2 \pi\left(t-t_{S}\right)+\left(C \frac{K}{2 \pi}\right) \sin 2 \pi\left(t_{o}-t_{S}\right)\right.}\right]\right],
$$

where, $L_{t}$ is length at age $t, L_{\infty}$ is the asymptotic length, $K$ is the growth rate parameter, $t_{0}$ is the nominal age at which the length is zero, $C$ is the relative amplitude $(0 \leq$ $C \leq 1)$ of the seasonal oscillations, $t_{S}$ is the phase of the seasonal oscillations $\left(-0.5 \leq t_{s} \leq 0.5\right)$ denoting the time of year corresponding to the start of the convex segment of sinusoidal oscillation.

The winter point $(W P)$, known as the slowest growth period during the year, was calculated as:

$W P=t_{S}+0.5$.

The goodness of fit $(R n)$ of the seasonal VBG curves to the data was calculated as:

$$
R n=\frac{10^{\frac{E S P}{A S P}}}{10}
$$

where $E S P$ is the explained sum of peaks, and $A S P$ is the available sum of peaks.

Analysis of the seasonal length data were fitted to length frequency distributions grouped in $0.5 \mathrm{~cm}$ TL size classes using the ELEFAN procedure (non-seasonal and Hoenig seasonal) in the LFDA ver. 5.0 (Kirkwood et al., 2003).
Growth performance comparisons were made using the growth performance index $\left(\Phi^{\prime}\right)$ which is preferred rather than using $L_{\infty}$ and $K$ individually (Pauly $\&$ Munro, 1984) and is computed as:

The growth performance index $\left(\Phi^{\prime}\right)$, preferred rather than using $L_{\infty}$ and $K$ individually, was used for comparison of growth performance (Pauly \& Munro, 1984) was calculated as:

$$
\Phi^{\prime}=\log _{10}(K)+2 \log _{10}\left(L_{\infty}\right) .
$$

Maximum life span for females and males were calculated using the empirical equation proposed by Taylor (1958) as:

The empirical equation proposed by Taylor (1958) was used for calculation of maximum life span for females and males as:

$$
A_{95}=t_{0}+\frac{2.996}{K}
$$

where, $\mathrm{A}_{95}$ is the life span as the time required to attain $95 \%$ of $L_{\infty}$, calculated from the Hoenig seasonal VBG equation.

Spawning period: The spawning period was graphically determined for both sexes by the monthly variation of the mean values of the gonadosomatic index $(G S I)$ as:

$$
\mathrm{GSI}=\frac{W g}{W} \times 100
$$

where, $W_{g}$ is gonad weight $(\mathrm{g}), W$ is total black goby weight $(\mathrm{g})$.

Size at sexual maturity $\left(L_{m}\right)$ : The size at sexual maturity (or the length at which $50 \%$ of a population become sexually mature for the first time) for black goby was calculated from the following empirical equation suggested for Ray-finned fish by Binohlan \& Froese (2009):

$\log L_{m}=-0.1189+0.9157 * \log \left(L_{\max }\right)$,

where, $L_{\max }$ is the observed maximum total length.

\section{RESULTS}

Population structure: A total of 568 (233 female and 335 male) specimens were sampled. The total length ranged between 2.2 and $12.1 \mathrm{~cm}$ (mean $5.7 \pm 0.1 \mathrm{~cm}, 95 \%$ conf.: 5.4-6.0 cm) for females and 2.1 and $14.6 \mathrm{~cm}$ (mean $5.9 \pm 0.1 \mathrm{~cm}, 95 \%$ conf: $5.7-6.2 \mathrm{~cm}$ ) for males (Figure 2). The difference between the mean total lengths is statistically insignificant $(P=0.324)$. Length frequency distribution (LFD) between sexes were not significantly different (Kolmogorov-Smirnov two-sample test; $d=0.672, P=$ 0.550). The mean $T L$ and also LFD were not significantly different between sexes $(\mathrm{P}>0.05)$. Therefore, the Hoeing seasonal and non-seasonal VBG parameters were estimated for combined sex and are shown in Table 1. 


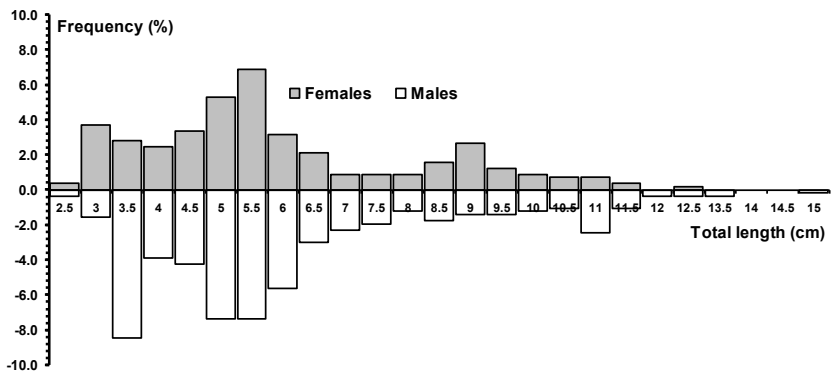

Figure 2. Length frequency distribution of females and males for Gobius niger around Rize province in the Southeastern Black Sea.

Table 1. The Hoenig seasonal and non-seasonal von Bertalanffy growth curve parameters estimated from the ELEFAN model and maximum life span for Gobius niger.

\begin{tabular}{lcc}
\hline \multirow{2}{*}{ Parameters } & \multicolumn{2}{c}{ ELEFAN Based Growth Model } \\
\cline { 2 - 3 } & Hoenig Seasonal & Non-Seasonal \\
\hline$L_{\infty}(\mathrm{cm})$ & 11.9 & 12.1 \\
$K\left(\right.$ year $\left.^{-1}\right)$ & 0.701 & 0.680 \\
$t_{0}($ year $)$ & -0.399 & -0.540 \\
$t_{S}$ & -0.008 & - \\
$W P$ & $0.492($ June $)$ & - \\
$C$ & 0.633 & - \\
$R n$ & 0.525 & 0.409 \\
$\Phi^{\prime}$ & 1.997 & 2.001 \\
$A_{95}$ (year) & 3.9 & 3.9 \\
\hline
\end{tabular}
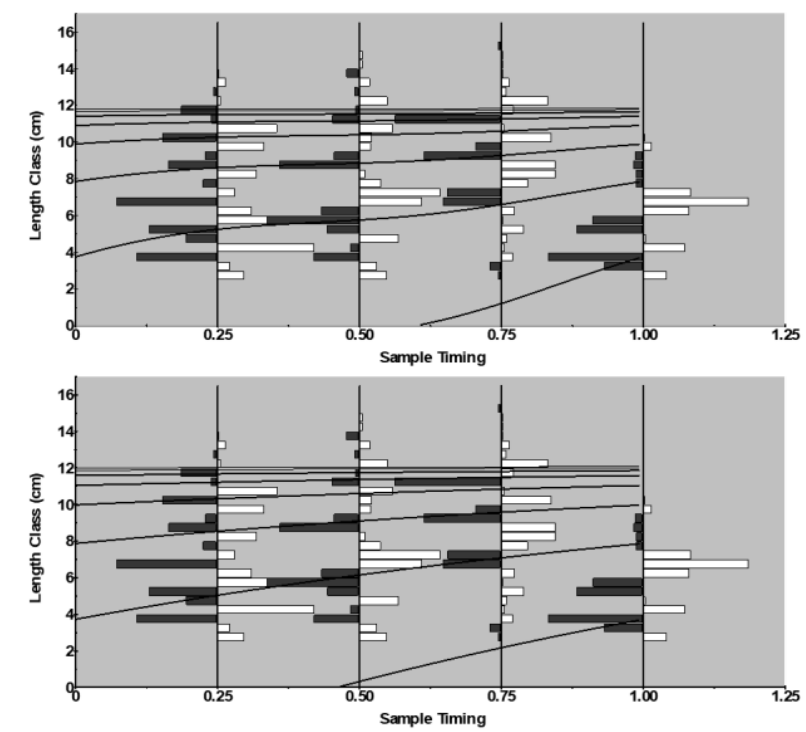

Figure 3. Length frequency distribution of Gobius niger with the Hoeing seasonal (A) and non- seasonal (B) von Bertalanffy growth curves (lines).

Growth curve parameters: Asymptotic total length and growth coefficient parameters were calculated as almost similar values for both seasonal $\left(L_{\infty}=11.9 \mathrm{~cm} \mathrm{TL}, K=0.701\right.$ year $\left.^{-1}\right)$ and non-seasonal $\left(L_{\infty}=12.1 \mathrm{~cm}\right.$ TL, $K=0.680$ year $\left.^{-1}\right)$ version of growth curve. The seasonal oscillations in growth was calculated as $C=$ 0.510 and the start of the slowest growth period was estimated in June ( $W P=0.492)$ (Figure 4). The $R n$ value of the non-seasonal growth curve improved $28.36 \%$ (Figure 3) when the seasonal growth curve was fitted, indicating that, at last for our data, black goby exhibits seasonal growth pattern. Growth performance indices $\left(\Phi^{\prime}\right)$ derived from seasonal (1.997) and non-seasonal (2.001) VBG parameters were fairly similar (Table 1). Maximum life span was also estimated as 3.9 years for both seasonal and non-seasonal version of the VBG curve parameters.

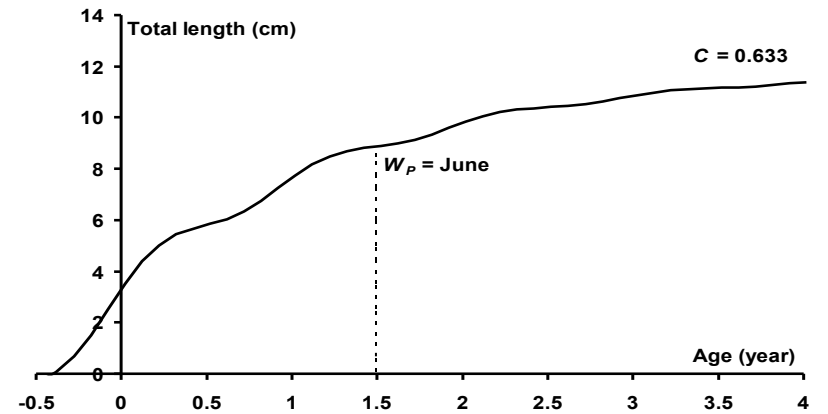

Figure 4. Winter point $(\mathrm{Wp})$ of the Hoenig seasonal von Bertalanffy growth curves for Gobius niger in the Southeastern Black Sea.

Spawning period: The GSI ranged between 0.60 in December 2012 and 8.57 in April 2013(mean = 3.82 \pm 0.82 , 95\% conf.: 2.05-5.58) for females and 0.61 in October 2013 and 2.90 in May 2013 (mean $=1.70 \pm 0.26,95 \%$ conf.: 1.13 2.27) for males. The differences between the mean GSI values of females and males were significantly different $(P=$ 0.0198). Female GSI values increased gradually from December to April and decreased gradually from April to August. Male GSI values increased from December to February and remain similar up to June (Figure 5b, c). These monthly variations of GSI values indicating that, at least for our data, the intensive spawning probably occurred between April and August. During these five months in spawning time, the mean GSI values of females $(6.037 \pm 1.177)$ was about 2.91 times higher than the mean GSI values of males $(2.079 \pm 0.423)(P=0.0133)$.
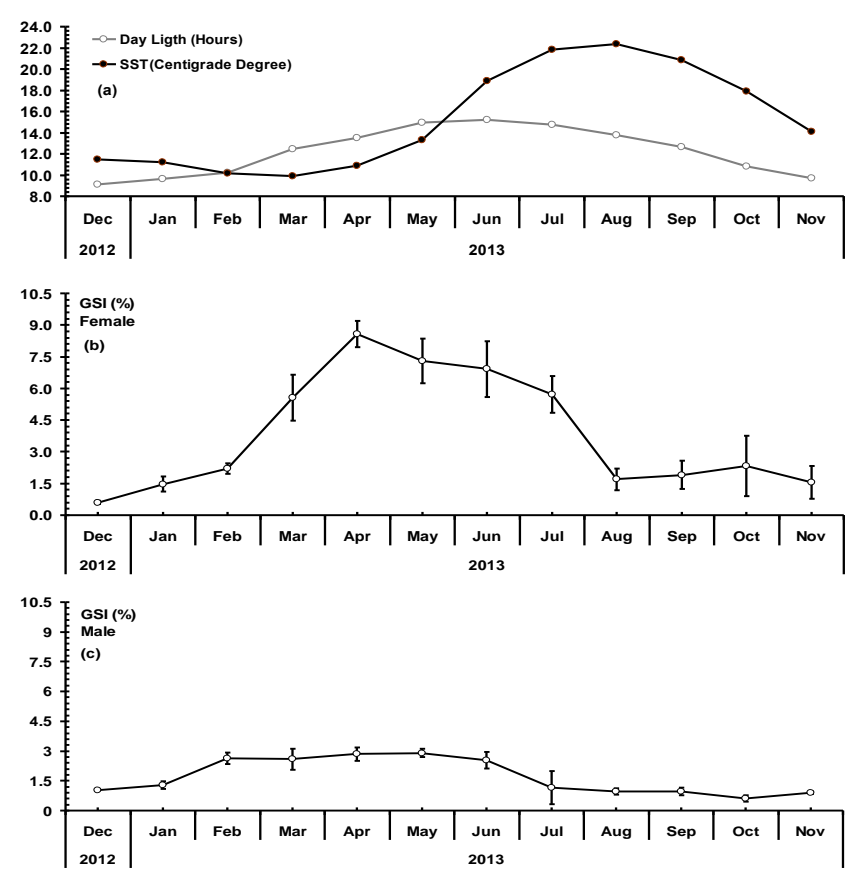

Figure 5. Monthly variations in day light (hours), Sea Surface Temperature (SST) (a) and in the Gonadosomatic index (GSI) values of females (b) and males (c) for Gobius niger, between December 2012 and November 2013 around Rize province in the southeastern Black Sea. Vertical lines indicate standard error (SE). 
Day light, which was 13.5 hours in April, regularly increases to reach the peak value in June (15.2 hours) and than continues to decrease regularly and reaches 12.6 hours in September. The sea surface temperature, which was $10.9^{\circ} \mathrm{C}$ in April, reaches its peak value $\left(22.3^{\circ} \mathrm{C}\right)$ in August and than continues to decrease regularly and reaches to the lowest value in November $\left(9.7^{\circ} \mathrm{C}\right)$ (Figure $\left.5 \mathrm{a}\right)$. When both water temperature and day light functions are considered together, it is clearly understood that the monthly variations of GSI values for both sexes are similar to day light variation rather than sea surface temperature functions. In other words, reproduction period is more related to day light rather than sea surface temperature (Figure 5a, b, c).

Size at sexual maturity $\left(L_{m}\right)$ : The $L_{m}$ was estimated from the empirical relationships between observed maximum total length and size at maturity. Thus, $L_{m}$ was estimated as $8.9 \mathrm{~cm} T L$ for both females and males.

\section{DISCUSSION}

Size and lifespan: The maximum total length of the black goby was reported as $14.3 \mathrm{~cm}$ (4 years) for females and $16.5 \mathrm{~cm}$ (5 years) for males in the Adriatic Sea, north of Ancona, Italy (Fabi \& Giannetti, 1985), $14.0 \mathrm{~cm}$ (4 years) for females and $15.2 \mathrm{~cm}$ (5 years) for males in the Aegean Sea, Izmir Bay, Turkey (Filiz \& Toğulga, 2009), $14.4 \mathrm{~cm}$ (4 years) for females and $16.1 \mathrm{~cm}$ (4 years) for males in the Marmara Sea, Turkey (Kurdar \& İşmen, 2018). In the Black Sea, around the Rize province, females obtained as $12.1 \mathrm{~cm}$ and males $14.6 \mathrm{~cm}$ (4 years) (Table 2). As can be understood from these explanations, in the different geographical regions, male black goby individuals live one year more than females and reach greater maximum length values as in the Black Sea. In this study, the average length values of the both sexes in the ages were not calculated. These calculations for Black Sea goby stocks need to be supported by future otolith-based growth studies. On the other hand, these differences between males and female's lifespan have been explained since females aged $2^{+}$have already spent too much energy during the reproduction activity, thus females are exposed to more biological stress than males and consequently only a few can survive their the $3^{\text {rd }}$ and/or $4^{\text {th }}$ year of life (Joyeux et al., 1991; Silva \& Gordo, 1997). This situation can be interpreted as the females are exposed to more natural mortality rates $(M)$ than males $\left(M_{\text {females }}>\right.$ $\left.M_{\text {males }}\right)$, especially after the breeding season. However, the effect of biological stress (e.g. $L_{\mathrm{m}}$, spawning duration and frequency) on mortality of this bio-indicator of environmental quality species (Maradonna \& Carnevali, 2007; Barucca et al., 2006) should be studied in more detail by participating in hydro-climatic conditions such as temperature, salinity, turbidity, etc.
Seasonal growth: In the Black Sea, together with seasonal water temperature changes and food condition, especially investments of energy in reproduction activity of the fish are the some of the major factors causing seasonality in growth (Bilgin et al., 2012, 2013). Therefore, both the Hoenig seasonal and non-seasonal von Bertalanffy growth models were applied for the black goby to obtain reliable and suitable growth parameters. The growth rates of black goby in the Black Sea are slightly high or similar when compared with other populations except for North Sea, Norway (higher latitude: $\left.59^{\circ} \mathrm{N}\right)($ Table 2$)$. The observed growth rates $(K>$ 0.68 ) indicate that examined species achieve asymptotic size quickly, even faster some of the other populations with different latitudes, such as Atlantic $\left(38^{\circ} \mathrm{N}\right)$, North Sea $\left(59^{\circ} \mathrm{N}\right)$, Adriatic Sea $\left(43^{\circ} \mathrm{N}\right)$, Aegean Sea $\left(38^{\circ} \mathrm{N}\right)$ and Sea of Marmara $\left(40^{\circ} \mathrm{N}\right)($ Table 2$)$. The higher growth rate for black goby was reported in the Ria de Aveiro Lagoon, Portugal than higher latitudes (Arruda et al., 1993). These differences among studies may have resulted from the difference between biotic (e.g. intraspecific competition, prey, predator, etc.) and abiotic factors (e.g. temperature, salinity, turbidity, etc.) (Kovačić \& Patzner, 2012; Kara \& Quignard, 2019).

To the best of our knowledge this is the first study to calculate the Hoenig seasonal growth curve parameters by using ELEFAN, to length-frequency data for the black goby. When there is a seasonal growth pattern for gobies belonging to the same family in a geographical region, the estimations of $L_{\infty}$ and $K$ may differ significantly between both the seasonal and non-seasonal models. In the present study, the non-seasonal VBG model provided mathematically and biologically realistic results. However, when seasonality was included (with the Hoenig model), more reliable values ( $R n=$ 0.525 ) were obtained, which confirmed the seasonality in the growth of the black goby. The $R n$ and $C$ values with visual growth curves (Figure 3,4) evidenced that this species exhibited marked seasonality in growth. Similar seasonal growth pattern was also reported for different fish species such as Anchovy, Engraulis encrasicolus (Linnaeus, 1758) (Bilgin et al., 2013) and Whiting, Merlangius merlangus (Linnaeus, 1758) (Bilgin et al., 2012) in the Black Sea. Since there is no information in the literature reporting the parameters showing seasonality in growth of the black goby, we were unable to compare our findings with others. However, the major factors that cause seasonality in the growth of marine organisms belong to different taxa were reported to be $i$ ) photoperiod, ii) variation in water temperature and salinity fluctuating over the year, iii) seasonal change in nutrient quality/availability, iv) energy input into reproduction during the breeding season $v$ ) intraspecific competition (Arruda et al., 1993; Bilgin, Özen \& Samsun, 2009a; Bilgin, Samsun \& Özen 2009b; OlayaRestrepo, Erzini \& González-Wangüemert, 2018). All these 
could be considered as the factors forcing seasonality in growth of the black goby (Figure 3,4) in the Black Sea. The period of slowest growth $(W P=0.492)$ for the black goby corresponded to June when the high reproduction activity occurs. Since the growth rate of fish depends on the food availability and temperature and also reproduction events, the slow growth of the black goby in June most likely could be due to the result of the investment of energy in reproduction inhibits growth. But, the effects of these factors on seasonal growth should be detail examined in future studies.

Table 2. Comparison of the VBG curve parameters $\left(L_{\infty}, K, t_{0}\right)$, maximum length $\left(L_{\max }, \mathrm{cm}\right)$, maximum life span $\left(t_{\max }\right.$, year), size at sexual maturity $\left(L_{m}, \mathrm{~cm}\right)$ and WLRs parameter $(b)$ for Gobius niger obtained in different areas. $L_{\infty}$, asymptotic total length $(\mathrm{cm})$; $K$, growth coefficient (year $\left.{ }^{-1}\right) ; t$, age at zero length; $\Phi^{\prime}$, growth performance index; M, males; F, females; C, combined (males + females). \#: calculated from $\Phi^{\prime}=\log 10(K)+2 \log 10\left(L_{\infty}\right) . \bullet: L_{m}$ calculated from $\log L_{m}=-0.1189+0.9157 \times \log \left(L_{\max }\right)$ empirical equation (Binohlan \& Froese, 2009).

\begin{tabular}{|c|c|c|c|c|c|c|c|c|c|c|c|}
\hline \multirow{2}{*}{ Study areas } & \multirow{2}{*}{ Latitute } & \multirow{2}{*}{ Sex } & \multicolumn{8}{|c|}{ Parameters } & \multirow{2}{*}{ References } \\
\hline & & & $\boldsymbol{L}_{\infty}$ & $K$ & $t_{0}$ & $\Phi^{\prime}$ & $L_{\max }$ & $t_{\max }$ & $L_{\mathrm{m}} \bullet$ & $b$ & \\
\hline \multirow[t]{2}{*}{ North Sea, Norway } & $59^{\circ} \mathrm{N}$ & $\mathrm{M}$ & 9.8 & 0.40 & & 1.58 & & 5 & & & Nash, (1984) \\
\hline & & $\mathrm{F}$ & 9.1 & 0.48 & & 1.60 & & 5 & & & \\
\hline \multirow[t]{3}{*}{ Adriatic Sea, Italy } & $43^{\circ} \mathrm{N}$ & M & 18.5 & 0.30 & -1.69 & 2.01 & 16.5 & 5 & 9.9 & & Fabi \& Giannetti, (1985) \\
\hline & & $\mathrm{F}$ & 16.9 & 0.20 & -2.57 & 1.74 & 14.3 & 4 & 8.7 & & \\
\hline & & $\mathrm{C}$ & & & & & & & & 3.14 & \\
\hline Atlantic, Portugal & $38^{\circ} \mathrm{N}$ & $\mathrm{C}$ & 16.7 & 0.34 & -1.91 & 1.97 & 15.0 & 3 & 9.1 & 3.26 & Silva \& Gordo (1997) \\
\hline Aegean Sea, Turkey & $38^{\circ} \mathrm{N}$ & $\mathrm{C}$ & 14.6 & 0.46 & -1.54 & 1.99 & & 3 & & 2.91 & Özaydın et al., (2007) \\
\hline Aegean Sea, Turkey & $38^{\circ} \mathrm{N}$ & $\mathrm{C}$ & 16.8 & 0.39 & -0.04 & 2.04 & & & & 3.26 & Kınacigil et al., (2008) \\
\hline \multirow[t]{3}{*}{ Aegean Sea, Turkey } & $38^{\circ} \mathrm{N}$ & $\mathrm{C}$ & 17.6 & 0.26 & -2.17 & 1.91 & 15.2 & 5 & 9.2 & 2.86 & Filiz \& Toğulga, (2009) \\
\hline & & M & 16.7 & 0.30 & -2.21 & 1.92 & 15.2 & 5 & 9.2 & 2.82 & \\
\hline & & $\mathrm{F}$ & 14.8 & 0.32 & -1.46 & 1.85 & 14.0 & 4 & 8.5 & 2.74 & \\
\hline \multirow[t]{3}{*}{ Marmara Sea, Turkey } & $40^{\circ} \mathrm{N}$ & $\mathrm{C}$ & 15.3 & 0.36 & -1.77 & 1.93 & 14.2 & 4 & 8.6 & 3.08 & Kırdar \& İşmen, (2018) \\
\hline & & M & 14.7 & 0.45 & -1.39 & 1.98 & 16.1 & 4 & 9.7 & 3.34 & \\
\hline & & $\mathrm{F}$ & 14.9 & 0.35 & -1.97 & 1.89 & 14.4 & 4 & 8.7 & 3.04 & \\
\hline \multirow[t]{4}{*}{ Black Sea, Turkey } & $41^{\circ} \mathrm{N}$ & $\mathrm{C}$ & 11.9 & 0.70 & -0.40 & 2.00 & 14.6 & 4 & 8.9 & 3.54 & Present study, the Hoenig \\
\hline & & $\mathrm{C}$ & 12.1 & 0.68 & -0.54 & 2.00 & 14.6 & 4 & 8.9 & 3.54 & Present study, non-seasonal \\
\hline & & M & & & & & 14.6 & & 8.9 & 3.51 & \\
\hline & & $\mathrm{F}$ & & & & & 12.1 & & 7.5 & 3.57 & \\
\hline
\end{tabular}

Table 3. Comparison of the spawning periods for Gobius niger in different areas. Oindicating reproduction period.

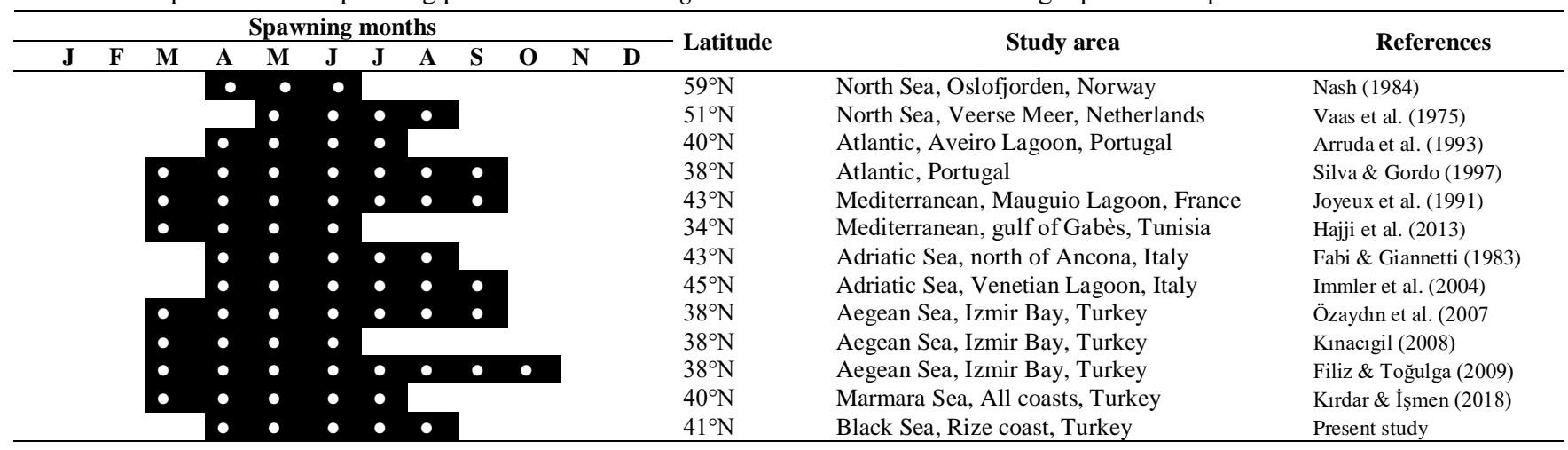

\section{Spawning period and size at sexual maturity}

The reported spawning periods for the black goby from different geographical areas and latitudes is shown in Table 3. Our results showed spawning period of the black goby lasted at least for five months in the Black Sea population (latitude: $41^{\circ} \mathrm{N}$ ), and this is in accordance with the Fabi \& Giannetti, (1983)'s results in the Adriatic Sea, north of Ancona, Italy (latitude: $45^{\circ} \mathrm{N}$ ). Furthermore, we realized that the variations of GSI values for both sexes of black goby coincide with the increase and decrease of daylight (Figure 5a, b, c). This result showed that the reproductive activity in the study area was related to daylight rather than temperature. Although spawning varies by region, it generally starts with spring and gains intensity in summer and ends in the first month of autumn
(September) (Table 3). However, spawning activities continue from 3 months in the North Sea, Oslofjorden, Norway at higher latitude $\left(59^{\circ} \mathrm{N}\right)(\mathrm{Nash}, 1984)$ to 8 months in the Aegean Sea, Izmir Bay, Turkey at lower latitude $\left(38^{\circ} \mathrm{N}\right)$ (Filiz \& Toğulga, 2009) (Table 3), depending on the regions and/or latitudes. According to Vaas et al., (1975) spawning begins when the temperature reaches $12^{\circ} \mathrm{C}$ in the North Sea, Veerse Meer, southern west Netherlands (latitude: $51^{\circ} \mathrm{N}$ ). The period was much shorter (about three months) in higher latitudes, in the North Sea coast of Norway (Nash, 1984), suggesting that the spawning period extent of the black goby was mainly determined by day light length and water temperature. However, reproduction cycle of the black goby is also affected by food condition (Kara \& Quignard, 2019). 
It has been reported that male individuals show different reproductive behavior characteristics (Mazzoldi \& Rasotto, 2002). In the Venetian lagoon, three types of males (large, small and intermediate) were defined according to their reproductive behavior. Namely, large males (> $9 \mathrm{~cm} \mathrm{TL}$ ) are nest-makers, aged 2 years or older. Small males (6-8 cm TL) are not nest-makers and gravitate around the nests of large males. Intermediate males behave either like sneakers or like nesting males, depending on the availability of nests and the level of competition between males (Mazzoldi \& Rasotto, 2002). In addition to these, male reproductive behaviors were not examined in this study, and it is important to examine the reproductive behavior of male individuals in future studies in the Black Sea region.

Geographic variations may affect the size of sexual maturity within a species (Kovačić \& Patzner, 2012; Kara \& Quignard, 2019). The size of sexual maturity $\left(L_{m}\right)$ was estimated as $8.9 \mathrm{~cm} T L$ for the black goby in this study. In other black goby populations, both smaller and larger in size than our study, $L_{m}$ was estimated as $4.3 \mathrm{~cm}$ TL in males and $5.4 \mathrm{~cm}$ in females (about 7 to $12-13$ months) in the Mauguio lagoon, France (Joyeux et al., 1991), as $6.0 \mathrm{~cm}$ TL $\left(0^{+}\right.$age) in the Ria de Aveiro lagoon, Portugal (Arruda et al., 1993), as 7.8 TL cm about 0.86 years for females in the Izmir Bay, Turkey (Filiz \& Toğulga, 2009) and $9.4 \mathrm{~cm}$ TL at one year in the Marmara Sea, Turkey (Kirdar \& İşmen, 2018). In the Gulf of Gabès (Tunisia, Mediterranean), $L_{m}$ was estimated as $10.1 \mathrm{~cm} T L$ in males and $9.7 \mathrm{~cm}$ in females (Hajji et al., 2013).

In conclusion, the presently reported study provides the first information on the seasonal growth, spawning period and size at maturity for the black goby in the Black Sea. The seasonal growth was more pronounced in the black goby, probably due to reproduction activity which extended investment of energy in reproduction causing slower growth of individuals. Reproduction period of the black goby in the Black Sea population was longer than the population in the Oslofjorden, Norway and in the Veerse Meer, Netherlands in the North Sea (Nash, 1984; Vaas et al., 1975) and in the Aveiro Lagoon, Portugal in the Atlantic (Arruda et al., 1993). The gonad development was initiated by photoperiod; whereas the duration of the breeding season was determined by water temperature depends on latitude levels. The results of this study were offered as biological input parameters regarded as a reference for the conservation and management of the Black Sea stocks of the black goby.

\section{ACKNOWLEDGEMENTS}

We thank to Ozay Köse, Burak Taşçı, Yusuf Ceylan and Ahmet Kalkavan for their help in the field work. We would also like to thank Ertuğrul Ağırbaş who provided the annual sea surface temperatures (SST) of the study area and thanks to 2 anonymous reviewers for improving the paper. This study was conducted in accordance with ethics committee procedures of animal experiments. This work was supported by Recep Tayyip Erdoğan University, Scientific Research Project Office (grant number 2010.103.03.1).

\section{REFERENCES}

Arruda, L., Azevedo, M.J.N. \& Neto, A.I. (1993). Abundance, age-structure and growth and reproduction of gobies (Pisces; Gobiidae) in the Ria de Averio Lagoon (Portugal). Estuarine, Coastal and Shelf Science, 37, 509-523. DOI: 10.1006/ecss.1993.1070.

Barucca, M., Canapa, A., Olmo, E. \& Regoli, F. (2006). Analysis of vitellogenin gene induction as valuable biomarker of estrogenic exposure in various Mediterranean fish species. Environmental Research, 101, 68-73. DOI: 10.1016/j.envres.2005.07.002.

Beverton, R.J.H. \& Holt, S.J. (1957). On the dynamics of exploited fish populations. Hmso, London, UK, $533 \mathrm{p}$.

Bilgin, S., Özen, Ö. \& Samsun, O. (2009a). Sexual seasonal growth variation and reproduction biology of the rock pool prawn, Palaemon elegans (Decapoda: Palaemonidae) in the southern Black Sea. Scientia Marina, 73, 239-247. DOI: 10.3989/scimar.2009.73n2239.

Bilgin, S., Samsun, O. \& Özen, Ö. (2009b). Seasonal growth and reproduction biology of the Baltic prawn, Palaemon adspersus (Decapoda: Palaemonidae), in the southern Black Sea. Journal of the Marine Biological Association of the United Kingdom, 89, 509-519. DOI: 10.1017/S0025315408003056.

Bilgin, S., Bal, H. \& Taşçi, B. (2012). Length based growth estimates and reproduction biology of whiting, Merlangius merlangus euxinus (Nordman, 1840) in the southeast Black Sea. Turkish Journal of Fisheries and Aquatic Sciences, 12, 871-881. DOI: 10.4194/1303-2712v12_4_15.

Bilgin, S., Taşçi, B. \& Bal, H. (2013). Sexual seasonal growth of the European anchovy (Engraulis encrasicolus) caught by mid-water trawl and purse seine in the southern Black Sea. Journal of the Marine Biological Association of the United Kingdom, 93, 333-339. DOI: 10.1017/S0025315412000732. 
Binohlan, C. \& Froese, R. (2009). Empirical equations for estimating maximum length from length at first maturity. Journal of Applied Ichthyology, 25, 611613. DOI: 10.1111/j.1439-0426.2009.01317.x.

Bouchereau, J.L. \& Guelorget, O. (1998). Comparison of three gobiidae (teleostei) life history strategies over their geographical range. Oceanologica Acta, 21, 503-517. DOI: 10.1016/S03991784(98)80034-0.

Casabianca, M.L. \& Kiener, A. (1969). Gobiidés des étangs corses. Systématique, écologie, régime alimentaire et position dans les chaînes trophiques. Vie et Milieu A 20, 611-634.

Çakıroğlu, A.M., N.K. Cevher \& Ağırbaş, E. (2017). The meteorological investigation of Turkish coasts of the Black Sea. Journal of Anatolian Environmental and Animal Sciences, 2, 53-58.

Fabi, G. \& Giannetti, G. (1985). Growth parameters of the black goby (Gobius niger L.) in the Adriatic Sea, based on otolith readings. Rapports Commission Internationale pour l'Exploration Scientifique de la Mer Méditerree, 29, 87-90.

Filiz, H. \& Toğulga, M. (2009). Age and growth, reproduction and diet of the black goby, (Gobius niger) from Aegean sea, Turkey. Journal of Fisheries sciences.com, 3, 243-265.

Franco, A., Riccato, F., Malavasi, S., Franzoi, P. \& Torricelli, P. (2006). Food resource utilization by gobies (Pisces, Teleostei) in the shallows of the Venice lagoon. Biologia Marina Mediterranea, 13, 866-868.

Froese, R. \& Pauly, D. (2019). FishBase. World Wide Web electronic publication. Available at http://www.fishbase.org. Version (12/2019) (Accessed online 12 June 2019).

Hajji, F., Ouannes-Ghorbel, A., Ghorbel, M. \& Arboui, O.J. (2013). Reproductive biology of the black goby, Gobius niger (Teleostei: Gobiidae), in the Gulf of Gabès (Tunisia, Central Mediterranean). Journal of Marine Biological Association of the United Kingdom, 93, 1685-1693. DOI: 10.1017/S0025315412001981.

Hammer, Ø., Harper, D.A.T. \& Ryan, P.D. (2001). PAST: Paleontological Statistics Software Package for Education and Data Analysis. Palaeontologia Electronica, 4, 1- 9.

Immler, S., Mazzoldi, C. \& Rasotto, M.B. (2004). From sneaker to parental male: change of reproductive traits in the black goby, Gobius niger (Teleostei, Gobiidae). Journal of Experimental Zoology, 301, 177-185. DOI: 10.1002/jez.a.20019.

Joyeux, J.C., Bouchereau, J.L. \& Tomasini, J.A. (1991). La reproduction de Gobius niger (Pisces,
Gobiidae) dans lagune de MauguioFrance: rapports gonosomatiques, fecondites, ponte, oeufs et larves. Vie et Millieu, 41, 97- 106.

Kara, M.H. \& Quignard, J-P. (2019). Fishes in lagoons and estuaries in the Mediterranean 2, sedentary fish. Wiley, London, UK, 396p.

Kınacıgil, H.T., İlkyaz, A.T., Metin, G., Ulaş, A., Soykan, O., Akyol, O. \& Gurbet, R. (2008). Determination of size at sexual maturity, ages and growth parameters of Aegean Sea demersal fish stocks in terms of fisheries management. The scientific and technological research council of Turkey (TUBITAK), Ankara, no 103Y132, 327 pp.

Kırdar, F. \& İşmen, A. (2018). Some population parameters of black goby (Gobius niger Linnaeus, 1758) in the Sea of Marmara. Comu Journal of Marine Science and Fisheries, 1, 7-12.

Kirkwood, G.P., Aukland, R. \& Zara, S.J. (2003). Software: Length Frequency Distribution Analysis (LFDA) Version 5.0. London: Marine Resources Assessment Group (MRAG) Ltd. Press.

Kovačić, M. \& Patzner, R.A. (2012). North-Eastern Atlantic and Mediterranean gobies. In Patzner R.A., Tassell J.M, Kovacic M. and Kapoor B.G (eds) The Biology of Gobies. New York, CRC Press, pp. 177-206.

Le Cren, E.D. (1951). The length-weight relationship and seasonal cycle in gonad weight and condition in the perch (Perca fluviatilis). Journal of Animal Ecology, 20, 201-219.

Maradonna, F. \& Carnevali, O. (2007). Vitellogenin, zonaradiata protein, cathepsin $\mathrm{D}$ and heat shock protein 70 as bio markers of exposure to xenobiotics. Biomarkers, 12, 240-255. DOI: 10.1080/13547500601070859.

Mazzoldi, C. \& Rasotto, M.B. (2002). Alternative male mating tactics in Gobius niger, Journal of Fish Biology, 61, 157-172. DOI: 10.1111/j.10958649.2002.tb01743.x

Nash, R.D.M. (1984). Aspects of biology of the black goby, Gobius niger L., in: Oslofjorden, Norway. Sarsia, 69, 55-61.

Olaya-Restrepo, J., Erzini, K. \& GonzálezWangüemert, M. (2018). Estimation of growth parameters for the exploited sea cucumber Holothuria arguinensis from South Portugal. Fishery Bulletin, 116, 1-8. DOI: 10.7755/FB.116.1.1.

Özaydın, O., Taşkavak, E. \& Akalın, S. (2007). Growth and reproduction of the black goby, (Gobius niger Linnaeus, 1758), in the locality Tuzla-iskele of 
Izmir Bay. Turkish Journal of Aquatic Life, 1, 411.

Pauly, D. (1984). Fish population dynamics in tropical water: a manual for use with programmable calculators. Makati, Metro Manila: The International Center for Living Aquatic Resources Management Press. Manila, Philippines, 325p.

Pauly, D. \& Munro, J.L. (1984). Once more on the comparison of growth in fish and invertebrates. ICLARM Fishbyte 2, 21.

Silva, M.N. \& Gordo, L.S. (1997). Age, growth and reproduction of the black goby, Gobius niger, from Obidos Lagoon, Portugal. Cahiers de Biologie Marine 38, 175-180.

Snedecor, G.W. \& Cochran, W.G. (1989). Statistical methods, 8th ed., Iowa State University Press, Ames, USA, 503p.

Somers, I.F. (1988). On a seasonally oscillating growth function. Fishbyte 6, 8-11.

Taylor, C.C. (1958). Cod growth and temperature. Journal du Conseil Permanent International pour l'Exploration de la Mer, 23, 366-370.

Vaas, K.F., Vlasbom, A.G. \& Koeijer, P. (1975). Studies on the black goby (Gobies niger, Gobiidae, Pisces) in the Verse Meer, SW Netherlands. Netherlands Journal of Sea Research, 9, 56-68.

von Bertalanffy, L. (1938). A quantitative theory of organic growth (Inquires on growth laws II). Human Biology, 10, 181-213.

Wood, L. (2015). Sea Fishes of the Mediterranean Sea including marine invertebrates. 2nd ed., Bloomsbury, London, UK, 128p. 